\title{
STRATEGI DINAS PERINDUSTRIAN DAN PERDAGANGAN KOTA PALANGKA RAYA DALAM MENINGKATKAN PENGELOLAAN PASAR TRADISIONAL KAHAYAN
}

\section{Strategy of the Department of Industry and Trade of the City of Palangka Raya in Improving the Management of the Kahayan Traditional Market}

\section{Mita Sari $I^{\text {I* }}$ \\ ISMAWATI $2^{2}$}

\begin{abstract}
*IUniversitas Muhammadiyah Palangkaraya I, Palangka Raya, Indonesia

2 Universitas Muhammadiyah Palangkaraya 2 Palangka Raya, Indonesia

Email: mitasyaja@gmail.com
\end{abstract}

\begin{abstract}
Abstrak
Di Kota Palangka Raya sekarang ini terjadi fenomena menjamurnya pasar modern ditengah - tengah keberadaan pasar tradisional hal ini menimbulkan banyaknya persepsi di masyarakat yang beragam. Tujuan penelitian ini untuk mengetahui strategi dinas perindustrian dan perdagangan kota palangka raya dalam meningkatkan pengelolaan pasar tradisional Kahayan.

Berdasarkan hasil penelitian, Strategi Pemerintah Daerah dalam Pengelolaan Pasar Tradisional sudah berjalan cukup baik. Pemerintah Kota sendiri senantiasa memberikan anggaran untuk pengelolaan pasar. Pada masa Covid-19 seperti saat ini Pemerintah Kota juga menerapkan layanan berbelanja online dan pesan antar guna menjauhi penyebaran Covid-19.

Saran yang dapat diberikan dalam penelitian ini adalah I) Diharapkan bagi Pemerintah Kota yang bertugas dalam pengelolaan pasar selalu melakukan pengawasan terhadap Pasar Tradisional Kahayan. 2) Diharapkan bagi Dinas Perindustrian Dan Perdagangan Kota Palangka Raya selalu mengadakan sosialisasi terhadap pedagang agar para pedagang memenuhi segala bentuk tata tertib demi kenyaman bersama. 3) Bagi masyarakat pedagang yang menggunakan lahan atau toko/ kios/ lapak diharapkan selalu mentaati peraturan yang di keluarkan oleh Pemerintah Kota.
\end{abstract}

Kata Kunci:

Peran

Pengelolaan

Pasar Tradisional

Keywords:

Role

Management

Traditional Market

\begin{abstract}
In Palangka Raya City, there is a phenomenon of the proliferation of modern markets in the midst of the existence of traditional markets, this has led to many perceptions in various communities. The purpose of this study was to determine Strategy of the Department of Industry and Trade of the City of Palangka Raya in Improving the Management of the Kahayan Traditional Market.

Based on the research results, the Regional Government Strategy in Traditional Market Management has been running quite well. The City Government itself always provides a budget for market management. During the Covid-19 period, as currently, the City Government has also implemented online shopping and delivery services to avoid the spread of Covid-19.

Suggestions that can be given in this study are I) It is expected that the City Government in charge of market management always supervises the Kahayan Traditional Market. 2) It is hoped that the Department of Industry and Trade of the City of Palangka Raya will always hold outreach to traders so that traders fulfill all forms of order for the sake of mutual comfort. 3)For merchant communities who use land or shops/kiosks/ stalls, they are expected to always obey the regulations issued by the City Government.
\end{abstract}




\section{PENDAHULUAN}

Masyarakat perkotaan kini sangat dimanjakan oleh berbagai pusat perbelanjaan. Terkadang letak perbelanjaannya saling berdekatan satu dengan yang lainnya, baik yang tradisional maupun yang modern. Kondisi ini sangat menguntungkan masyarakat karena mereka tinggal memilih gerai mana yang akan dituju. Namun disisi lain, pasar tradisional yang memasok kebutuhan konsumen lambat laun tergencat. Maraknya bisnis retail (ritel) juga dialami di Indonesia. Bisnis ini sudah bukan hanya berdiri di kabupaten dan perkotaan saja, melainkan sekarang sudah berdiri di berbagai kecamatan maupun perdesaan. Contoh bisnis ritel yang terkenal di kalangan masyarakat saat ini yaitu Alfamart dan Indomaret. Maraknya bisnis eceran yang terjadi saat ini sangat menumbuhkan minat berbelanja di kalangan masyarakat, karena baik Alfamart dan Indomaret menyediakan berbagai macam produk sehari-hari dengan harga yang sudah tertera jelas dalam produk, ketersediaan layanan 24 jam, tempat lebih nyaman, lebih bersih, sistem pemilihan dan pengambilan barang sendiri oleh konsumen sehingga memudahkan masyarakat untuk membeli serta mendapatkan barang yang dibutuhkan dengan segera. Selain itu dengan pelayanan yang ramah dan sering melakukan diskon serta promo produk, Alfamart dan Indomaret sangat diapresiasi keberadaannya oleh masyarakat sekitar karena sangat memuaskan. Bahkan dengan berbelanja di Alfamart maupun Indomaret dengan memiliki kartu keanggotaan, konsumen akan mendapatkan poin atau mendapat potongan harga (Masyhuri et al., 2017).

Seiring perkembangan zaman dan diimbangi dengan kemajuan teknologi yang sangat pesat, modernisasi diberbagai bidang yang menawarkan berbagai macam kemudahan dan kenyaman yang ditawarkan oleh berbagai pusat perbelanjaan yang semakin modern yang banyak dipromosikan oleh berbagai macam media, menimbulkan dampak yang kurang menguntungkan dan secara perlahan mengusik keberadaan pasar tradisional

Hal ini dapat dilihat dari banyaknya usaha kecil dan menengah yang mengalami gulung tikar, PHK yang mengakibatkan penurunan taraf hidup dan kondisi ekonomi masyarakat. Banyak usaha masyarakat seperti toko sembako, toko pakaian dIl yang kemudian tutup karena ketidakmampuan para pedagang dan pemerintah untuk membekali dan menyiapkan diri agar dapat adaptif terhadap perubahan dan tuntutan konsumen yang lebih variatif dan kekinian, selain itu modernisasi dan kemajuan teknologi yang begitu pesat tidak mampu di imbangi oleh sebagian besar masyarakat/pedagang sehingga mengakibatkan mereka terjebak pada kondisi yang staknan dan lebih buruk terutama omset dan minat masyarakat terhadap produk semakin menurun. Padahal pasar tradisional merupakan kekuatan ekonomi rakyat, pasar tradisional memiliki potensi untuk menciptakan dan memperluas lapangan kerja, terutama bagi tenaga kerja yang kurang memiliki kemampuan dan keahlian yang memadai untuk bekerja di sektor formal karena rendahnya tingkat pendidikan yang mereka miliki. Bahkan pasar tradisional secara nyata mampu memberikan pelayanan terhadap kebutuhan masyarakat yang berpenghasilan rendah, sehingga dengan demikian tercipta suatu kondisi pemerataan hasil-hasil pembangunan. Selain itu, pasar tradisional sebagai sarana perputaran ekonomi, sumber kehidupan masyarakat kota juga sumber Pendapatan Asli Daerah (PAD) bagi kota Palangka Raya.

Menurut Kementrian Perdagangan jumlah pasar modern yang ada di Indonesia kini mencapai 23.000 pasar. Sedangkan menurut Ikatan Pedagang Pasar Indonesia (IKAPPI) jumlah pasar tradisional 9.950 pasar dalam kurun waktu 4 tahun terakhir. Data AC Nielsen yang lain (2013) juga menyebutkan bahwa jumlah pasar tradisional di Indonesia terus berkurang dari tahun ke tahun. Tahun 2007, jumlah pasar tradisional 13.550 unit. Tahun 2009 menjadi 13.450 
unit. 2011 turun drastis menjadi 9.950 unit (Hendrianto, 2018).

Seperti yang bisa kita lihat banyak sekali kios yang tutup dan tempatnya di bangun pasar modern seperti Alfamart dan Indomaret. Pasar tradisional yang ditemui sekarang pada umumnya dapat hidup berdampingan dengan perdagangan yang dikelola lebih modern, seperti kios dan toko. Jika mereka mampu lebih adaptif terhadap perkembangan zaman dan tentunya dalam hal ini juga harus mendapat perhatian dari pemerintah. Mengingat betapa pentingnya keberadaan pasar maka penulis tertarik membahas lebih lanjut dalam penelitian yang berjudul Strategi Pemerintah Daerah Kota Palangka Raya Dalam Meningkatkan Pengelolaan Pasar Tradisional

\section{METODOLOGI}

Jenis penelitian yang digunakan yaitu deskriptif kualitatif. Menurut Sugiyono (2017:9), Metode penelitian kualitatif adalah metode penelitian yang berlandaskan pada filsafat potspositivisme digunakan untuk interpretif, digunakan untuk meneliti pada kondisi objek yang alamiah, dimana peneliti adalah sebagai instrument kunci, teknik pengumpulan data dilakukan secara triangulasi, data yang diperoleh cenderung data kualitatif, analisis data bersifat induktif/kualitatif dan hasil penelitian kualitatif bersifat untuk memahami makna, memahami keunikan, mengkontruksi fenomena, dan menentukan hipotesis.

Adapun fokus pada penelitian ini adalah Strategi Dinas Perindustrian Dan Perdagangan Kota Palangka Raya dalam meningkatkan pengelolaan Pasar Tradisional. Selain itu, peneliti juga bermaksud memahami situasi sosial secara mendalam dan menguraikan sifat-sifat dari suatu keadaan yang ditempuh melalui observasi dengan melihat keadaan sekitar objek penelitian dan menggunakan wawancara sebagai alat pengukur data.

Untuk memperoleh data dan informasi yang dilakukan, maka teknik pengumpulan data terdiri dari :

I. Observasi

2. Wawancara, dan

3. Dokumentasi.

\section{HASIL DAN PEMBAHASAN}

\section{Hasil Penelitian}

Pada dasarnya manajemen pasar tradisional meliputi pengelolaan dan pemberdayaan pasar tradisional. Berdasarkan Peraturan Menteri Dalam Negeri Republik Indonesia No 20 Tahun 2012 tentang Pengelolaan dan Pemberdayaan Pasar Tradisional. Pengelolaan pasar tradisional adalah penataan pasar tradisional yang meliputi perencanaan, pelaksanaan, dan pengendalian pasar tradisional, sementara itu pemberdayaan pasar tradisional adalah segala upaya pemerintah daerah dalam melindungi keberadaan pasar tradisional agar mampu berkembang lebih baik agar tidak tertinggal oleh perkembangan zaman dan mampu bersaing dengan pasar modern.

Tujuan dari manajemen pasar tradisional adalah sebagai berikut :

I) Menciptakan, memperluas dan meratakan kesempatan kerja dibidang perdagangan.

2) Meningkatkan pendapatan dan kesejahteraan masyarakat.

3) Memanfaatkan sumber daya milik pemerintah daerah untuk kepentingan masyarakat.

4) Memberikan kesempatan kepada masyarakat atau badan dalam mengelola dan memanfaatkan pasar untuk kemajuan daerah.

5) Mempertahankan, menjaga dan melestarikan pasar sesuai peran dan fungsinya sebagai lembaga ketahan ekonomi, sosial dan budaya.

Kemajuan sebuah organisasi atau lembaga bergantung pada pengelolaannya, baik dari pihak manajer maupun staf-staf kepegawaiannya. Sebuah organisasi yang baik tentunya memiliki kepengurusan keorganisasian yang mampu mengelola dan mengontrol laju perkembangan organisasi tersebut.

Sebagaimana yang telah dipaparkan penulis pada bab sebelumnya dalam Peraturan Menteri Perdagangan No. 53/M-DAG/PER/I2/2008 dijelaskan bahwa pasar tradisional adalah pasar yang dibangun dan dikelola oleh pemerintah, pemerintah daerah, swasta, badan usaha milik negara dan badan usaha milik daerah termasuk kerjasama dengan swasta dengan tempat usaha berupa toko, kios, los dan tenda yang dimiliki/dikelola oleh pedagang kecil, menengah, swadaya masyarakat atau koperasi dengan usaha skala kecil, modal kecil dan dengan proses jual beli barang dagangan melalui tawar menawar. 
Hasil penelitian merupakan gambaran data dan fakta yang didapatkan peneliti dari lapangan berdasarkan hasil temuan penelitian melalui pengamatan dan wawancara oleh peneliti kepada berbagai informan yang ada di lapangan serta disesuaikan dengan teori yang digunakan peneliti yaitu Teori Manajemen menurut George R. Terry disebutkan bahwa ada 4 fungsi-fungsi manajemen diantaranya yaitu Perencanaan (Planning), Pengorganisasian (Organizing), Pelaksanaan (Actuating), dan Pengawasan (Controlling) terkait dengan strategi pemerintah daerah dalam meningkatkan pengelolaan Pasar Tradisional.

Pasar Kahayan termasuk pasar Tradisional tetapi Pasar ini merupakan perpaduan antara Pasar Tradisional dan juga Pasar Modern. Pasar Kahayan sendiri memiliki beberapa tenaga kontrak yang terdiri dari 28 Petugas Kebersihan, 22 Satpam, 5 Resepsionis dan 3 teknisi. Kemudian Pasar ini juga sudah ditetapkan sebagai Pasar Tertib Ukur jadi pasar ini memiliki Pos Ukur Ulang mereka melakukan tera ulang yang dilakukan tiap I tahun sekali yaitu alat ukur Takar, Timbang, dan Kelengkapannya.

Pasar Kahayan merupakan salah satu pasar yang aman dari bahan-bahan berbahaya seperti boraks, formalin, rodamin dan itu sudah ditetapkan oleh Pemerintah Pusat secara Nasional jadi Kota Palangka Raya mendapatkan penghargaan secara Nasional.

Pasar Pemerintah ini merupakan sumber Pendapatan Asli Daerah (PAD) seluruh pasar pemerintah memiliki target I,4 Miliar dalam setahun untuk PAD sendiri. Pada saat Pandemi Covid-19 ini pendapatan berkurang karena banyak orang yang berbelanja online, menjamunya pasar modern yang jaraknya tidak terlalu jauh dari pasar tradisional. Kenapa demikian karena untuk berbelanja online ataupun berbelanja di pasar modern sendiri kita tidak berinteraksi langsung dengan penjual dan tidak berkumpul banyak dengan para pembeli lain.

\section{Pembahasan Penelitian}

\section{Strategi Pemko terhadap Pengelolaan PasarTradisional Kahayan}

Agar tidak tertinggal oleh keberadaan Pasar Modern UPTD Pasar sendiri memiliki beberapa Strategi terhadap Pasar Tradisional :

I. Modernisasi di aspek bangunan pasar yang dibuat seperti menyerupai mall-mall besar.
2. Harga sewa yang dibuat lebih murah. Harga sewa yang dibuat bervariasi seperti lapak harga sewa dimulai dari Rp. 17.000 rupiah - Rp. 200.000

3. Penataan Kios dan lapak yang dibuat serapi mungkin

4. Menyediakan area parkir yang luas. Akan tetapi ada beberapa jalan diarea parkir yang rusak sehingga jalan tidak terlihat baik.

5. Memiliki Petugas Keamanan dan Kebersihan sama seperti yang ada di Pasar Modern

6. Memiliki Resepsionis

7. Memiliki Pos ukur ulang tetapi ini juga tidak efesien karena takutnya terjadi kecurangan pada pembeli

Strategi Dinas Perdagangan Koperasi, Usaha Kecil Menengah dan Perindustrian Kota Palangka Raya terhadap pengelolaan Pasar Tradisional yaitu Berkesinambungan. Pemko sendiri senantiasa memberikan anggaran untuk pengelolaan di Pasar karena disatu sisi pengelolaan di pasar tradisional sendiri menghasilkan Pendapatan Asli Daerah (PAD) untuk Pemerintah Kota. Dalam hal ini seperti pemasukan sewa lapak dll yang diterima UPTD Pasar itu diharapkan dikembalikan lagi ke pengguna kios dan lapak yang digunakan sebagai perbaikan sarana dan prasarana yang ada sehingga apapun yang berkaitan dengan kenyamanan para penjual maupun para pembeli.

Dan yang berkaitan dengan pandemi disana melayani pedagang tanpa kontak fisik jadi pasar tetap berjalan tetap bisa bertransaksi seperti biasa. Pasar Kahayan merupakan salah satu pasar yang sudah menerapkan Layanan Berbelanja Online dan Pesan Antar. Karena Pasar Kayahan sekarang ini bekerja sama dengan Gojek sehingga bisa dilakukan Delivery, on request pembelanjaan sehingga roda ekonomi di Pasar ini bisa berputar. Pola yang akan dilakukan berbelanja secara daring tersebut bisa melalui telepon atau Aplikasi WhatsApp khusus yang sudah disediakan dan yang dikelola oleh Unit Pelaksana Teknis Daerah (UPTD) Pasar Kota Palangka Raya.

Pemerintah kota juga merencanakan akan menambah jumlah maupun lokasi berbelanja online atau pesan antar. Khususnya di setiap Pasar Tradisional yang ada di Kota Palangka Raya. Sehingga warga tidak perlu repot-repot lagi untuk berbelanja ke pasar. Namun bisa mengubungi nomor-nomor pedagang sebagaimana yang sudah dikeluarkan UPTD Pasar.

UPTD Pasar juga melakukan update harga 9 bahan pokok langsung terkoneksi ke kementrian perdagangan yang dijalankan langsung dari Dinas perdagangan. Pada tahun 2017 dulu pernah dilakukan pelatihan untuk Manajemen Penjualan dan Kiat-kiat 
untuk membangun usaha.

Startegi dan Arahan Kebijakan Kota Palangka Raya untuk mewujudkan Kota Palangka Raya sebagai Kota tujuan wisata dan jasa untuk meningkatkan kemandirian ekonomi masyarakat dengan :

I. Meningkatkan lapangan kerja

2. Meningkatkan pertumbuhan sektor industri dan jasa berbasis pariwisata yang ramah lingkungan

3. Meningkatkan dan menciptakan jaringan pasar produk unggulan

Dengan adanya strategi diatas pemerintah daerah mempunyai strategi arah kebijakan dengan sasaran peningkatan kelancaran distribusi barang dan jasa dan penggunaan produk dalam negeri, meningkatkan tumbuhnya industri kecil dan menengah, meningkatkan kualitas dan kuantitas dan mutu produk, mengembangkan produk-produk UMKM dan Koperasi yang berdaya saing, Meningkatkan akses pemodalan UMKM dan Koperasi juga meningkatkan pengembangan kualitas kelembagaan Koperasi dan UMKM.

Kota Palangka Raya memiliki posisi yang strategis dalam rangka pengembangan ekonomi wilayah dan merupakan pusat pertumbuhan ekonomi, walaupun sebagian besar barang dan jasa yang diperdagangkan didatangkan dari luar daerah. Pengembangan dan pembinaan terhadap sektor perdagangan dan jasa ditujukan untuk meningkatkan dan menjamin lancarnya distribusi barang kebutuhan pokok dan barang strategis. Sektor perdagangan merupakan sektor yang sangat dominan di Kota Palangka Raya baik dilihat dari pangsanya maupun tingkat pertumbuhannya.

I. Perencanaan (Planning)

Pada segi perencanaan Pasar Kahayan dapat dikatakan sudah baik, hal ini dapat dilihat dari segi pengelolaan pasar yang dilakukan pemerintah dan juga SOP yang sudah jelas dalam penepatan tujuantujuan dan penepatan strategi-strategi yang digunakan untuk tujuan tersebut tercapai seperti :

a) UPT Pasar berdiri pada tahun 2017

b) Memberikan uraian tugas, tupoksi dan SOP

c) Disperindag menyiapkan angsuran belanja UPT Pasar

d) Disperindag menyiapkan penambahan PTT (Pegawai tidak tetap) pada UPT Pasar

e) Pembuatan bangunan baru pada Pasar Kahayan

Berdasarkan uraian diatas bahwa kebijakan Disperindag dapat diartikan sebagai penyempurnaan dan pembenahan pasar. Dalam hal ini kegiatan-kegiatan yang telah direncanakan pemerintah agar tujuan yang diinginkan tercapai.
2. Pengorganisasian (Organizing)

Berdasarkan segi pengorganisasian pasar Kahayan sudah terlaksana dengan baik, hal ini dapat dilihat dari bagaimana para petugas pasar yang sudah melaksanakan tugas mereka secara maksimal. Mulai dari biaya sewa kios/ toko, retribusi parkir, karcis perhari yang dipungut petugas dan juga biaya pemeliharaan pasar. Dalam hal ini juga diharapkan kepada pedagang untuk bekerjasama dengan para petugas agar tidak ada kendala yang terjadi. Pelaksanaan ini dilakukan bertujuan untuk meningkatkan Pendapatan Asli Daerah dan dapat Meningkatkan pengelolaan pasar tradisional.

3. Pelaksanaan (Actuating)

Dalam hal pelaksaan Disperindag juga sudah pernah melakukan bimbingan motivasi kepada pedagang bagaimana cara bekerja secara efektif dan efisien untuk mencapai tujuan. Pada tahun 2017 dulu pernah dilakukan pelatihan untuk Manajemen Penjualan dan Kiat-kiat untuk membangun usaha.

4. Pengawasan (Controlling)

Untuk proses pengawasan sendiri dilakukan oleh para petugas pasar untuk mengawasi para pedagang yang menggunakan kioskios, los dan toko, sehingga mereka menggunakan tempat tersebut dengan tertib dan teratur agar tidak menimbulkan hal-hal yang tidak diinginkan. Para petugas harus siap mengawasi setiap saat, memantau sehingga apa yang direncanakan dapat dilaksanakan sesuai dengan tujuan yang diinginkan.

\section{KESIMPULAN}

Hasil penelitian yang berkaitan dengan Strategi Dinas Perindustrian Dan Perdagangan Kota Palangka Raya Meningkatkan Pengelolaan Pasar Tradisional Kahayan dapat disimpulkan sudah sangat cukup baik karena UPT Pasar sendiri mengerti dengan keadaan masyarakat yang ada dan di Pasar Kahayan sendiri seperti Sewa Kios/lapak yang sangat murah, disediakan parkir yang luas, memiliki petugas keamanan dan kebersihan sama seperti yang ada di Pasar Modern dan yang paling penting di Pasar Kahayan disediakan Pos ukur ulang atau tera ulang yang belum ada di Pasar Tradisional manapun di Kota Palangka Raya walaupun pos ukur ulang ini sendiri belum terbilang efesien karena takutnya terjadi kecurangan. Dan pada masa 
pandemi seperti saat ini Pasar Kayahan bekerja sama dengan Gojek guna memutus penyebaran Covid-19 sehingga bisa dilakukan Delivery, on request pembelanjaan sehingga roda ekonomi di Pasar ini bisa berputar. Kebijakan yang dilakukan ini sangat baik dimasa sekarang sehingga diharapkan terciptanya beberapa pembaharuan-pembaharuan di kegiatan jual beli

\section{UCAPAN TERIMA KASIH}

Terima kasih serta penghargaan kepada pihakpihak yang telah berpartisipasi dalam kegiatan penelitian yang dilakukan yaitu FISIPOL Universitas Muhammadiyah Palangkaraya, narasumber, organisasi dan unsur masyarakat, yang telah membantu pelaksanaan kegiatan penelitian

\section{REFERENSI}

Arianty, Nel. (2013) Analisis Perbedaan Pasar Modern Dan Pasar Tradisional Di Tinjau Dari Strategi Tata Letak (Lay Out) Dan Kualitas Pelayanan Untuk Meningkatkan Posisi Tawar Pasar Tradisional, Jurnal.

Dewi, Dian Sukma. (2018). Dampak Keberadaan Pasar Modern Terhadap Pendapatan Para Pedagang Pasar Tradisional (Studi Kasus Di Desa Tanggul Angin Kecamatan Punggur), Skripsi. IAIN Metro.

Drucker, P.F. (2000). Pemimpin masa depan. Jakarta: PT Elex Media Komputindo.

Firdaus, Rizky. (2020). Strategi Kantor Urusan Internasional Dalam Peningkatan Motivasi Peserta KKN Luar Negeri Universitas Muhammadiyah Palangkaraya, Skripsi, Universitas Muhammadiyah Palangkaraya.

Hendrianto. (2018). Manajemen Strategi Pengelolaan Pasar Dalam Meningkatkan Pendapatan Pedagang Perspektif Ekonomi Islam, Skripsi, IAIN Purwokerto.
Hunger, J.D. and Wheelen, T.L. (2003). Manajemen Strategis. Terjemahan: Agung, Julianto. Yogyakarta: Andi.

Irawan. (2018) Analisis Manajemen Pengelolaan Pasar Tradisional Sebagai Sumber Pendapatan Daerah Di Pasar JelojokDesa Kopang Kec. Kopang Kab. Lombok Tengah Dalam Perspektif Manajemen Syariah, Skripsi, Universitas Islam Negeri Mataram.

Islamy, I. (1997). Prinsip-Prinsip Perumusan Kebijaksanaan Negara. Jakarta: Penerbit PT Bumi Aksara.

Kuncoro, M. (2006). Strategi: Bagaimana Meraih Keunggulan Kompetitif. Jakarta: Erlangga.

Ling. (20I2). Peraturan Republik Indonesia No. II2, Jurnal.

Lubis. M.S. (2000). Reformasi Politik dan Hukum. Bandung: Mandar Madju.

Mankiw, G. (2003). Makro Ekonomi. Jakarta: Erlangga. Responsif. Bandung: Hakim Publishing.

Masyhuri, Mahmudah.; Utomo, Supri Wahyudi. (2017). Jurnal Akuntansi Dan Pendidikan Vol 6 No I April 2017 Halaman 59-72.

Pasolong, Harbani. (20II). Teori Administrasi Publik. Bandung : Alfabeta

Rahman, Luqman Abdul. (20/9). Analisis Pengaruh Pasar Modern Terhadap Omzet Pedagang Pasar Tradisional, Skripsi, Universitas Islam Negeri Sumatera Utara.

Revitasari, Evi. (2017). Pengelolaan Pasar Tradisional Oleh Dinas Perindustrian Dan Perdagangan Di Kabupaten Lebak, Skripsi, Universitas Sultan Ageng Tirtayasa.

Sarwoko, Endi. (2008). Dampak Keberadaan Pasar Modern Terhadap Kinerja Pedagang Pasar tradisional Di Wilayah Kabupaten Malang, Jurnal. Syafiie, Inu Kencana. 2006. Ilmu Admimnistrasi Publik, Cetakan. Pt Rineka Cipta, Jakarta.

Sugiyono, (20/4). Metode Penelitian Kuantitatif Dan Kualitatif Dan R \& D, Bandung : Alfabeta

Sugiyono, (2017). Metode Penelitian Kualitatif Dan Kuantitatif Dan R \& D, Bandung : Alfabeta 
Sugiyono, Prof. Dr. (2016). Journal Of Chemical Information and Modeing. Jurnal.

Superti, Indah. (2017). Analisis Pengelolaan Pasar Tradisional Guna Meningkatkan Pendapatan Pedagang Kecil Dalam Perspektif Ekonomi Islam (Studi Kasus Pasar Simpang Agung, Desa Simpang Agung, Lampung Tengah), Skripsi. UIN Raden Intan Lampung.

https://konsultanbisnis.id/pengertian-strategic-planning/ (Diakses Pada 29 Oktober 2020 Pukul 20:04 WIB)

https:/www.maxmanroe.com/vid/bisnis/pengertiananalisis-swot.html (Diakses Pada 29 Oktober 2020 Pukul 20:24 WIB 